Journal of Education and Teaching Learning (JETL)

Volume 3, Issue 1, January 2021

Journal Homepage:

http://pusdikra-publishing.com/index.php/jetl

\title{
Pelayanan Profesional Guru Bimbingan Konseling Dalam Meminimalisir Kesalahpahaman Tentang Bimbingan Konseling Di Sekolah
}

\author{
Azmatul Khairiah Sari ${ }^{1}$, Prayitno ${ }^{2}$, Yeni Karneli ${ }^{3}$ \\ 1,2,3 Universitas Negeri Padang
}

Corresponding Author azmatulkhairiah998@gmail.com

\begin{tabular}{|c|c|}
\hline & ABSTRACT \\
\hline $\begin{array}{l}\text { ARTICLE INFO } \\
\text { Article history: } \\
\text { Received } \\
25 \text { December } 2020 \\
\text { Revised } \\
\text { 07 January } 2021 \\
\text { Accepted } \\
\text { 23 January } 2021\end{array}$ & $\begin{array}{l}\text { Guru bimbingan konseling adalah penyelenggara kegiatan bimbingan } \\
\text { konseling di sekolah. Guru bimbingan konseling harus memiliki empat } \\
\text { kompetensi. Kompetensi kepribadian, kompetensi profesional, } \\
\text { kompetensi sosial dan kompetensi pedagogik. Kompetensi profesional } \\
\text { adalah kompetensi yang penting bagi seorang guru karena guru harus } \\
\text { profesional di bidangnya. Profesional yang menandakan ia adalah orang } \\
\text { yang ahli untuk melaksanakan pelayanan bimbingan konseling. Seorang } \\
\text { guru BK harus memberikan pelayanan profesional kepada siswanya di } \\
\text { sekolah. Dengan pelayanan profesional diharapkan guru BK memiliki } \\
\text { image positif dari siswanya dan masyarakat luas lainnya. Adanya image } \\
\text { ini tentu akan memiliki dampak terhadap penilaian bagaimana } \\
\text { bimbingan konseling tersebut. Banyaknya kesalahpahaman tentang } \\
\text { Bimbingan Konseling menyebabkan keprofesionalan Bimbingan } \\
\text { Konseling menjadi tercemar. Menganggap guru Bimbingan Konseling } \\
\text { yang tidak profesional, guru Bimbingan Konseling hanya tidak memiliki } \\
\text { kejelasan dalam bekerja dan banyak lagi anggapan miris mengenai } \\
\text { Bimbingan Konseling oleh siswa dan pihak lainnya. Pada dasarnya } \\
\text { bimbingan konseling merupakan suatu profesi yang diakui oleh Undang- } \\
\text { Undang namun bagi sebagian yang lainnya itu dipandang sebelah mata. } \\
\text { Diharapkan dengan adanya pelayanan profesional dari guru Bimbingan } \\
\text { konseling bisa mematahkan anggapan salah mengenai bimbingan } \\
\text { konseling dan bisa meminimalisir kesalahpahaman tentang bimbingan } \\
\text { konseling. Dengan adanya pelayanan profesional dari guru bimbingan } \\
\text { konseling membuktikan bahwa seorang guru adalah seorang yang benar } \\
\text { profesional. Pelayanan profesional yang dilaksanakan oleh guru } \\
\text { bimbingan konseling menandakan seorang guru bimbingan konseling } \\
\text { layak untuk menjadi seorang guru. Dan dengan profesionalnya ini bisa } \\
\text { meminimalisir kesalahpahaman tentang bimbingan konseling. }\end{array}$ \\
\hline
\end{tabular}

Key Word Pelayanan, Profesional, Kesalahpahaman, Bimbingan Konseling

Azmatul Khairiah Sari , Prayitno, Yeni Karneli, Pelayanan Profesional

How to cite Guru Bimbingan Konseling Dalam Meminimalisir Kesalahpahaman Tentang Bimbingan Konseling Di Sekolah, Journal Of Education And Teaching Learning (Jetl).

\section{PENDAHULUAN}

Pendidikan menjadi suatu kebutuhan dewasa ini untuk banyak pihak. Dengan pendidikan maka individu memahami apa yang ada disekitarnya. 
Pentingnya pendidikan ini telah diatur dalam Undang-Undang No.20 Tahun 2003 tentang sistem pendidikan nasional pasal 1 butir 1 yang meyatakan bahwa pendidikan adalah usaha sadar dan terencana untuk mewujudkan suasana belajar dan proses pembelajaran agar peserta didik secara aktif mengembangkan potensi dirinya untuk memiliki kekuatan spiritual keagamaan, pengendalian diri, kepribadian, kecerdasan, akhlak mulia, dan keterampilan yang diperlukan dirinya, masyarakat, bangsa dan agama.

Dari Undang-Undang ini dapat diambil kesimpulan bahwa pendidikan adalah sebuah proses yang didalamnya terdapat sebuah usaha dari pendidik untuk yang dididiknya dan merencanakan seperti apa bentuk pendidikan yang akan diberikannya pada peserta didiknya. Dan peserta didik diminta aktif dalam suasana pendidikan agar ia bisa mengembangkan potensi-potensi dalam dirinya masing-masing. Dan dengan potensi yang ada maka ia akan mencapai tujuan pendidikan yang telah diusahakan dan direncanakan oleh pendidiknya. Yang pada akhirnya bermuara pada kebergenuaan peserta didik oleh nusa bangsa dan agama.

Dalam undang-undang pendidikan juga disebutkan bahwa konselor adalah pendidik. Dia membelajarkan kliennya untuk menguasai keterampilan tertentu. Konselor mengupayakan terjadinya perubahan tingkah laku pada klien dan pencapaian kehidupan efektif sehari-hari untuk klien tersebut. Guru bimbingan konseling dituntut profesional dalam mengerjakan pelayanan konseling kepada kliennya. Hal ini dilakukan dalam wujud motivasi altruistik yang dimiliki guru bimbingan konseling tersebut. Guru bimbingan konseling dihadapkan pada keadaan dimana ia harus bersikap profesional dalam situasi menghadapi kliennya. Guru bimbingan konseling harus menjalankan layanan yang ada di dalam BK dengan profesional. Melaksanakan pelayanan dengan memulai dengan need assessment untuk kliennya. Dan dari olahan hasil need asessment akan diketahui apa materi yang diinginkan oleh klien tersebut. Yang menjadi sasaran pelayanan bimbingan konseling di sekolah adalah siswa yang berada di sekolah. Siswa yang memang membutuhkan arahan seperti apa baiknya ke depan, siswa yang sedang mencari jati diri, dan siswa yang memang belum memahami dirinya secara utuh. Siswa-siswa ini dibantu oleh guru bimbingan konseling untuk menyelesaikan masalah belajarnya dan masalah yang berkaitan dengan kehidupannya.

Dalam memberikan layanan Bimbingan dan Konseling (Bimbingan dan Konseling), guru bimbingan kosenling di sekolah menjalankan pelayanan BK sesuai dengan peraturan yang ada. Selain itu pelaksanaan layanan bimbingan konseling sejalan dengan tujuan pendidikan di sekolah tersebut. Setiap guru bimbingan konseling mengampu 150 orang siswa sebagai siswa asuhnya. 
Dikarenakan sebuah sekolah memiliki siswa lebih dari 150 orang maka dibutuhkan lebih dari satu orang guru BK. Maing-masing guru BK memiliki tanggung jawab untuk menjalankan pelaksanaan bimbingan konseling secara profesional baik secara individu mapun secara berkelompok. Secara berkelompok maka diperlukan adanya koordinasi dari satu guru Bk dengan guru BK lainnya.

Tugas utama guru BK adalah melaksanakan bimbingan dan konseling bagi siswa asuhnya. Seberapa besar keberhasilan yang dicapai guru BK dalam melaksanakan kegiatan di sekolah sekaligus pula dijadikan sebagai tolak ukur akan kemampuannya dalam melaksanakan peran di sekolah. Untuk itu, seluruh perencanaan BK, pelaksanaak BK, dan evaluasi BK harus disusun sedemikian rupa oleh guru bK dan tidak terlepas koordinasi dengan personal sekolah lainnya agar tujuan di sekolah tersebut tercapai.

Namun dalam pelaksanaan BK masih ada pernyataan kurang mengenakkan mengenai BK. Anggapan-anggapan ini terarah pada pelaksanaan BK yang masih dianggap abal-abalan. Guru BK yang dianggap sebagai polisi sekolah, Guru BK yang dianggap tidak menjalankan tanggung jawab dan fungsinya di sekolah, BK tidak perlu ada di Sekolah dan masih banyak anggapan miris lainnya tentang BK. Maka penulis disini ingin sedikit mengulas pentingnya keprofesionalan seorang guru BK dalam meminimalisir anggapananggapan yang tidak menyenangkan tersebut. Atau biasa kita sebut dengan kesalahpahaman tentang BK. Dan diharapkan dengan adanya keprofesionalan seorang guru BK maka kesalahpahaman tentang BK akan berkurang dan siswa akan merasakan bagaimana BK itu bagi dirinya dan mengubah lingkungannya. Dengan adanya rasa kepuasan atas keprofesionalan BK oleh guru BK maka siswa akan menyampaikan bahwa BK itu bagus dan anggapan selama ini bisa terpatahkan.

\section{METODOLOGI PENELITIAN}

Artikel ini merupakan penelitian kualitatif. Jenis artikel ini termasuk dalam kategori penelitian kepustakaan (library research). Teknik pengumpulan data dengan melakukan penelaahan terhadap buku, literatur, catatan, serta berbagai laporan yang berkaitan dengan masalah yang ingin dipecahkan. penelusuran pustaka lebih daripada sekedar melayani fungsi-fungsi yang disebutkan untuk memperoleh data penelitiannya. Tegasnya riset pustaka membatasi kegiatannya hanya pada bahan-bahan koleksi perpustakaan saja tanpa memerlukan riset lapangan (Zed, 2018: 1-2).

Ketereampilan profesional dalam hal ini adalah kemampuan yang terlatih dan sudah memiliki lisensi dari pihak yang memang memiliki hak untuk 
memberikan lisensi kepada konselor tersebut. Serta konselor adalah guru BK yang menamatkan s1 bimbingan konseling dan akan lebih bagusnya jika ia sudah mengambil profesi konselor. Sementara kesalahpahaman BK adalah hal yang dirasakan oleh masyarakat dan pihak sekolah yang menganggap bahwa BK adalah bukan suatu profesi.

Dalam hal ini adalah yaitu, pertama, dengan mencatat semua temuan mengenai keterampilan profesional guru BK/Konselor secara umum pada setiap pembahasan penelitian yang didapatkan dalam literatur-literatur dan sumber-sumber dan jurnal yang berkaitan dengan keterampilan profesional konselor. Setelah mencatat, kedua, memadukan segala temuan, baik teori atau temuan baru pada keterampilan profeional konselor. Setelah itu menganalisis sumber-sumber bacaan tersebut dan mengkritisi bahan bacaan tersebut.

\section{HASIL PENLITIAN DAN PEMBAHASAN Pelayanan Guru Bimbingan Konseling Profesional}

Bimbingan dan konseling (BK) terdiri dari kata bimbingan dan konseling. Bimbingan merupakan terjemahan dari kata guidance dalam bahasa inggris yang berarti to direct, pilot, manager, onsteer yang artinya menunjukkan, mengarahkan, menentukan, mengatur, atau mengemudikan (Shetzer, 1976: 3). Bimbingan dan Konseling adalah pelayanan yang dilaksanakan dari manusia, untuk manusia, dan oleh manusia (Arsini, 2017). Bimbingan dan konseling (BK) terdiri dari kata bimbingan dan konseling. Bimbingan merupakan terjemahan dari kata guidance dalam bahasa inggris yang berarti pertolongan yang diberikan untuk menuntun individu atau kelompok guna mencapai hidup yang lebih sejahtera (Batubara, 2018). Bimbingan konseling dilaksanakan oleh guru BK dan diberikan kepada siswa asuhnya dan bersama-sama guru dan siswa menuju kepada tujuan bimbingan konseling yang diharapkan.

Siswa di sekolah akan menghadapi permasalahan yang membutuhkan orang lain untuk memecahkan permasalahannya. Tohirin, mengatakan bahwa secara umum masalah-masalah yang dihadapi oleh siswa adalah masalahmasalah pribadi, masalah belajar, masalah pendidikan, masalah karir atau pekerjaan, penggunaan waktu luang dan masalah-masalah sosial (Thohirin, 2007: 3). Guru BK tentu harus memahami bidang apa permasalahan siswa tersebut. Guru BK membantu penyelesaian masalah siswa sesuai dengan bidang masalah tersebut.

Bimbingan dan konseling merupakan proses pemberian bantuan kepada individu secara berkelanjutan dan sistematis, yang dilakukan oleh seorang ahli yang telah mendapatkan latihan khusus untuk itu, dengan tujuan agar individu dapat memahami dirinya, lingkungannya, serta dapat mengarahkan diri dan 
menyesuaikan diri dengan lingkungannya untuk mengembangkan potensi dirinya secara optimal untuk kesejahteraan dirinya dan kesejahteraan masyarakat (Shalahuddin, 2010: 16). Dari pengertian ini diketahui bahwa bimbingan konseling dilaksanakan agar individu bisa mencapai kemandirian dalam hidupnya. Dengan kemandirian tersebut ia bisa menghadapi sendiri permasalahannya. Kemandirian menjadikan klien tangguh dalam menerima permasalahan tersebut dan mengontrol dirinya dalam menghadapi permasalahan tersebut.

Yang melaksanakan bimbingan konseling di sekolah adalah guru BK itu sendiri. Menne dalam Annas menyebutkan bahwa seorang konselor harus memiliki karakteritik :

a. Memahami dan melaksanakan etika profesional

b. Mempunyai rasa kesadaran diri mengenai kompetensi, nilai-nilai dan sikap

c. Memeiliki karakteristik diri, yakni respek terhadap orang lain, kematangan pribadi, memiliki kemampuan intuitif, fleksibel dalam pandangan dan emosional stabil

d. Kemampuan dan kesabaran untuk mendegarkan orang lain, kemampuan berkomunikasi (shalahuddin, 2010: 194).

Rogers mendefenisikan bahwa aspek kepribadian konselor yang penting dalam hubungan konseling adalah: empati, respek, menerima, menghargai, memahami dan jujur. Bahkan Rogers menyatakan bahwa kepribadian lebih besar perannya dibandingkan teknik. Jadi, seorang guru BK harus memiliki keterampilan profesional dalam dirinya sehingga ia akan menjiwai proses konseling dengan sebaik-baiknya. Pandai menempatkan diri, dan tidak mencampur adukkan

Perkembangan keprofesionalan dimulai melalui lima tahapan atau melalui lima periode besar. Adapun periodenya adalah (Prayitno, 2018: 3):

a. Tahap pertama, sebagai rintisan berlangsung sampai dihasilkannya lulusan jurusan bimbingan dan penyuluhan yang pertama di IKIP Bandung tahun 1965.

b. Tahap kedua, masuknya gerakan BP di sekolah sampai dengan diberlakukannya kurikulum 1975 di seluruh tanah air yang di dalamnya memuat BP. Disisi lain terbentuknya organisasi profesi Ikatan petugas Bimbingan Indonesia (IPBI).

c. Tahap ketiga, pada tahapan ini istilah BP disempitkan artinya menjadi bimbingan karier.

d. Tahap keempat, pada periode ini berkembang teori, praksis dan praktek pelayanan konseling dengan konsep yang lebih terarah, yaitu 
dengan diubahnya secara resmi "bimbingan penyuluh" menjadi "bimbingan Konseling dan diaplikasikannya BK pola 17 plus. Pada periode ini juga pada tahun 1999 dibuka program Pendidikan Profesi Konselor di Universitas Negeri Padang.

e. Tahap kelima, pada tahap ini dibukalah PPK ke-2 di Universitas negeri Semarang. Maka untuk meningkatkan Konseling bermartabat didoronglah kampus lain untuk mendirikan program Profesi Konselor. Dan pada tahap ini juga dibentuk organisasi profesi yaitu Ikatan Konselor Indonesia (IKI).

Adanya Program Profesi Konselor untuk menciptakan sarjana BK yang memang profesional dibidangnya. Dengan adanya keprofesionalan maka guru BK yang ada disekolah bisa melaksanakan pelayanan BK secara profesional. Kualitas konselor adalah semua kriteria keunggulan, termasuk pribadi, pengetahuan, wawasan, keterampilan dan nilai-nilai yang dimilikinyayang akan memudahkannya dalam menjalankan proses konseling sehingga mencapai tujuan dengan berhasil (Willis, 2009: 79). Seorang guru BK yang sudah profesional akan memiliki keunggulan yang diharapkan dalam pelaksanaan bimbingan konseling.

Ada beberapa kompetensi yang harus dikuasai oleh seorang konselor. Kompetensi ini untuk melambangkan keprofesionalan seorang guru BK di sekolah. Kompetensi tersebut adalah (Prayitno, 2009: 67):

a. Kompetensi pedagogik

- Menguasai teori dan praksis pendidikan

- Mengaplikasikan perkembangan fisiologis dan psikologis serta perilaku konseli

- Menguasai esensi pelayanan bimbingan konseling dalam jalur, jenis dan satuan pendidikan

b. Kompetensi kepribadian

- Beriman dan bertaqwa kepada Tuhan Yang Maha Esa

- Menghargai dan menjunjung tinggi nilai-nilai kemanusiaan, individualitas dan kebebasan memilih

- Menunjukkan integritas dan stabilitas kepribadian yang kuat

- Menampilkan kinerja berkualitas tinggi

c. Kompetensi sosial

- Mengimplementasikan kolborasi interen di tempat bekerja

- Berperan dalam organisasi profesi dan kegiatan profesi bimbingan dan konseling

- Mengimplementasikan kolaborasi antar profesi 
Journal of Education and Teaching Learning (JETL)

Volume 3, Issue 1, January 2021

Page 36-49

d. Kompetensi profesional

- Menguasai konsep dan praksis asesmen untuk memahami kondisi, kebutuhan, dan masalah konseli

- Menguasai kerangka teoritik dan praksis bimbingan konseling

- Merancang program bimbingan dan konseling

- Mengimplementasikan program bimbingan dan konseling yang komprehensif

- Menilai profesi dan hasil kegiatan bimbingan dan konseling

- Memiliki kedasaran dan komitmen terhadap etika profesional

- Menguasai konsep dan praksis penelitian dalam bimbingan dan konseling.

Keutuhan kompetensi ini tidak dipisahkan dan harus saling bersinergi dan saling berkaitan (Lestari, dkk, 2013). Tidak akan berarti kompetensi pedagogik apabila tidak sesuai dengan kompetensi lainnya. Namun masingmasing guru harus memiliki keempat kompetensi ini agar bagus dilapangan. Begitu juga guru BK tentu harus memiliki kompetensi ini dalam dirinya.

Guru bk yang bisa menguasai empat kompetensi ini maka ia akan bisa menjalankan pelayanan bimbingan konseling dengan profesional. Ia memiliki latar belakang pendidikan yang sesuai dengan bidangnya, ia bisa berinteraksi dengan sosial dan ia memiliki kepribadian yang sesuai dengan nilai-nilai tepat. Maka guru BK harus mengimplementasikan kompetensi ini kepada kliennya dan orang sekitarnya agar nampak profesionalnya BK tersebut.

Ke empat kompetensi ini saling berintegrasi untuk membentuk profesionalnya seorang konselor di mata klien, masyarakat dan lingkungan sekitarnya. Tidak bisa ditonjolkan hanya satu kompetensi saja. Kompetensi pedagogik tidak akan bermakna apabila kompetensi profesional tidak dimiliki. Dan kompetensi kepribadian tidak akan berimbang jika tidak dibarengi dengan kompetensi lainnya. Maka guru BK mengusahakan agar kompetensi ini meresap kedalam dirinya sehingga profeionalnya guru tersebut bisa dirasakan oleh klien atau siswa di sekolah tersebut.

Undang-Undang Nomor 12 Tahun 2012 Tentang Perguruan Tinggi dan peraturan menteri Pendidikan Dan Kebudayaan Nomor 81 Tahun 2014 tentang Ijazah, Sertifikat Kompetensi dan Sertifikat profesi pendidikan Tinggi bahwa tanda kelulusan program pendidikan profesi ada tiga yaitu:

a. Ijazah, sebagai tanda tamat menjalani program pendidikan dengan gelar profesi dilengkapai dengan SKPI (Surat Keterangan Pendamping Ijazah)

b. Sertifikat Kompetensi, sebagai tanda penguasaan kompetensi profesi 
c. Sertifikat Profesi, sebagai tanda kewenangan melaksanakan layanan Praktik Profesi.

Bagi lulusan profesi konselor memiliki legalitas untuk melaksanakan layanan bimbingan konseling secara profesional. Pelayanan konseling yang profesional akan menjadikan bimbingan konseling menjadi diperhitungkan oleh masyarakat banyak. Konseling profesional diberikan oleh guru BK yang profesional akan menjadikan siswa menjadi bersemangat mengikuti konseling.

Layanan yang profesional dari guru BK akan hadir apabila guru BK sendiri sudah menguasai keempat kompetensi. Guru bk hendaklah memiliki pengetahuan yang mendalam mengenai keilmuan yang akan ia praktekkan. Guru bk harus memiliki sosial yang baik sehingga ia bisa berinteraksi untuk mengembangkan BK di tengah-tengah masyarakat. Guru BK harus memiliki kepribadian yang berlandaskan pada pancasila. Karena pancasila merupakan landasan negara kita dan kepribadian guru BK diharapkan sejalan dengan nilai-nilai pancasila tersebut. Dan Guru BK harus memiliki keprofesionalan dalam menjalankan layanan-layanan yang ada di BK.

\section{Kesalah Pahaman Tentang Bimbingan Konseling}

Keberadaan bimbingan konseling di sekolah masih dipertanyakan oleh beberapa pihak. Bahkan ada yang menganggap enteng profesi guru BK tersebut. Disadari bahwa selama ini masih terjadi kesalahpahaman terhadap BK. Kesalahpahaman tersebut membuat kehadiran bimbingan dan konseling sebagai salah satu komponen layanan pendidikan belum menunjukkan eksistensinya sebagai layanan pendidikan yang sangat strategis untuk mencapai tujuan pendidikan(Ardimen, 2018). Sementara dari hasil penelitian Ong Didik Cahyo menyimpulkan masih banyak siswa dan guru yang belum memahami peranan dan fungsi BK, dan ada yang menafsirkan BK dengan image negatif. Bahkan ada yang yang mengatakan bahwa guru BK pemarah, galak dan kurang ramah (Kartiko, dkk, 2014). Dari persepsi ini bisa menimbulkan kesalahpahaman tentang BK itu sendiri.

Beberapa Kesalahfahaman yang terjadi dalam bimbingan konseling (Prayitno, 2004:120-129):

a. Bimbingan dan Konseling disamakan atau dipisahkan sama sekali dari pendidikan. Anggapan ini menyatakan bahwa bimbingan konseling memang tidak digabungkan sama sekali dengan pendidikan atau memang betul terpisah dari pendidikan karena dilaksanakan oleh orang yang ahli. Jawaban untuk kesalahfahaman ini sebenarnya sudah ada dimana sekolah hendaknya memang memasukkan unsur bimbingan konseling dalam pembelajarannya. Sehingga BK yang memang dasarnya sebagai pendidikan bisa 
menampakkan eksistensinya. Dan BK juga bukan hal mewah yang pelaksanaannya sangat susah dilakukan oleh orang yang benar-benar ahli. Padahal guru BK yang paling diutamakan adalah keterampilan dan keahliannya dalam memandu BK di sekolah tersebut.

b. Konselor di sekolah diperankan sebagai "polisi sekolah". Anggapan ini juga sebenarnya keliru. Konselor dianggap sebagai penanggung jawab kedisiplinan sekolah. Konselor dianggap sebagai orang yang ditakuti karena setiap bermasalah diminta ke ruangan guru BK. Hal ini tentu menciptakan image negatif bahwa kalau bertingkah laku yang salah maka akan dihadapkan pada konselor. Sehingga terkesan kalau siswa yang melanggar aturan akan diserahkan pada polisi sekolah.

c. Bimbingan dan konseling dianggap semata-mata sebagai proses pemberian nasehat. Nasihat adalah jurus jitu yang sering diberikan kepada siswa ketika ia bermasalah. Nasihat adalah salah satu sebagian kecil yang ada di konseling. Guru BK sebenarnya melakukan upaya untuk membantu siswa menyelesaikan masalahnya.

d. Bimbingan dan Konseling dibatasi pada hanya menangani masalahmasalah yang bersifat insidental. Sebenarnya konseling itu menjangkau dimensi waktu yang lebih luas, yaitu lalu, sekarang dan yang akan datang. Konselor tidah hanya menunggu saja klien datang dan mengemukakan masalahnya.

e. Bimbingan dan Konseling dibatasi hanya untuk peserta didik tertentu saja. Bimbingan konseling ditujukan pada siswa yang bermasalah saja. Jikapun ada pada penggolongan maka itu hanya kepada penggolongan masalah saja, bukan atas dasar kondisi pribadi klien. Semua siswa berhak mendapatkan kesempatan yang sama untuk mendapatkan bimbingan konseling.

f. Bimbingan dan Konseling melayani "orang sakit" dan/atau "kurang/tidak normal". Guru BK yang memiliki kemampuan tinggu akan dengan mudah mendeteksi dan mempertimbangkan lebih jauh tentang mantap atau kurang mantapnya fungsi-fungsi yang ada pada kloiennya sehingga klien tersebut perlu dikirim ke dokter atau psikiater atau tidak. Penanganan masalah oleh ahlinya secara tepat akan memberikan jasmani yang kuat bagi keberhasilan pelayanan.

g. Bimbingan dan Konseling bekerja sendiri, padahal sebenarnya guru BK harus bekerja sama dengan personil sekolah lainnya dalam melaksanakan bimbingan konseling. Bayangkan apabila guru BK 
sudah bisa merubah fikrian siswa yang malas untuk bisa hadir tepat waktu dikelas. Akan tetapi guru mata pelajaran malah memberikan sebuah cemoohan kepada siswa tersebut "tumben kamu tidak terlambat, tumben kamu rajin, mimpi apa semalam makanya kamu hadir tepat waktu" dan masih banyak kata ejekan yang bisa mematikan proses konseling yang sudah dibina oleh guru BK.

h. Konselor harus aktif, sedangkan pihak lain pasif, sesuai dengan azaz kegiatan disamping konselor yang bertindak sebagai pusat penggerak bimbingan dan konseling, pihak lainpun terutama klien, harus secara langsung aktif terlibat dalam proses tersebut. Pada dasarnya bimbingan konseling adalah usaha bersama yang beban kegiatannya tidak semata=mata ditimpakan hanya kepada konselor saja.

i. Menganggap pekerjaan bimbingan dan konseling dapat dilakukan oleh siapa saja. Salah satu ciri keprofesionalan bimbingan dan konseling adalah pelayanan itu harus dilakukan oleh orang-orang yang ahli dibidangnya. Keahliannya itu diperoleh melalui pendidikan dan latihan yang cukup lama di perguruan tinggi.

j. Pelayanan bimbingan konseling berpusat pada keluhan pertama saja. Pada umumnya memang diawali dengan melihat gejala-gejala keluhan awal yang disampaikan klien. Dan ternyata apabila maalah tersebut lebih didalami maka ini akan lebih luas lagi masalah yang sebenarnya dialami klien. Guru BK hendaknya tidak tertuju pada masalah pertama yang disampaikan klien saja. Hendaknya keluhan itu didalami dan akan nampaklah seperti apa masalahnya.

k. Menyamakan pekerjaan bimbingan dan konseling dengan pekerjaan dokter atau psikiater. Bimbingan konseling tidaklah persis sama dengan pekerjaan pekerjaan dokter dan psikiater. Bagi Bimbingan konseling yang dihadapi adalah orang sehat yang sedang mengalami masalah. Maka penyelesaian masalah ini bisa diupayakan untuk disembuhkan dengan cara memakai teknik-teknik dan pendekatan tertentu sesuai dengan masalah yang dihadapinya.

1. Menganggap hasil pekerjaa BK segera dilihat. Tuntutan yang cukup tinggi untuk BK adalah setelah siswa berhadapan dengan Guru BK maka ia akan langsung berubah. Padahal ini tentu memiliki proses yang harus dilewati klien tersebut.

m. Menyamaratakan cara pemecahan masalah bagi semua klien. Padahal sebenarnya masalah yang tampaknya sama belum tentu cara 
penyelesaiannya juga sama. Ada keunikan tersendiri yang dimiliki oleh individu dan masalah yang ia hadapi tersebut.

n. Memusatkan usaha bimbingan dan konseling hanya pada penggunaan instrumentasi BK. Sebenarnya penggunaan instrumen sebagai alat bantu untuk pelaksanaan bimbingan konseling. Tidak adanya instrumen ini bukan berarti bimbingan konseling tidak diadakan sama sekali. Namun adanya instrumentasi memang sebagai pembantu bagi guru BK untuk memudahkan dalam pemberian bimbingan konseling.

o. Bimbingan dan konseling dibatasi hanya menangani masalah yang ringan saja. Menetapkan masalah itu ringan atau berat bukanlah hal yang mudah. Terkadang bagi sebagian orang masalah ini berat tapi tidak untuk sebagian lainnya. Namun fokus bimbingan konseling adalah untuk menanganinya dengan cermat dan tuntas.

\section{Pelayanan Profesional Guru Bimbingan Konseling Dalam Meminimalisir Kesalahpahaman Tentang Bimbingan Konseling Di Sekolah}

Pelayanan bimbingan konseling yang dilakukan oleh guru BK hendaklah yang didasari pada keprofesionalan. Guru BK adalah seorang yang profesional dan akan menjalankan layanan Bimbingan konseling. Guru BK dalam melaksanakan tugas profesional yakni memberikan layanan bimbingan dan konseling kepada peserta didik, kepadanya berhak mendapatkan imbalan yang layak sebagai penghargaan atas kerja profesionalnya (Widada, 2018). Dari hasil penelitian Hazrullah menyatakan bahwa guru Bk yang memiliki ijazah sebagai seorang guru BK dan memiliki sertifikat konselor akan memberikan pelayanan yang profesional kepada siswanya (Hazrullah, dkk, 2018). Didukung dengan penelitian dari Abdul Murad bahwa guru BK yang berlatar pendidikan BK lebih memuaskan dalam mengunjukkerjakan konseling bagi pemenuhan kebutuhan perkembangan unik anak dan remaja daripada guru BK yang bukan berlatar pendidikan BK (Murad, 2011). Dari hal ini dapat dikatakan bahwa pentingnya profesional karena akan berpengaruh pada layanan yang diberikan oleh guru BK tersebut kepada siswa yang menjadi kliennya di sekolah.

Profesionalnya guru BK didapatkan melalui proses pendidikan. Dan selama dalam menempuh pendidikan tersebut banyak praktek dan teori yang sudah ia bahas. Dan tentunya akan lebih mantap aplikasinya dibandingkan guru BK yang bukan berlatar beakang pendidikan S1 BK. Dan pelayanan yang diberikan oleh guru BK profesional tentu akan sesuai dengan Standar Prosedur Operasional pada masing-masing layanan tersebut. Dan guru BK yang profesional memiliki relasi sesama rekan guru BK yang bisa memberikan pengalaman dan sharing ilmu pengetahuan. 
Pelayanan BK yang bisa dilaksanakan oleh guru BK adalah 10 jenis layanan dan enam kegiatan pendukung. Dengan 6 bidang bimbingan bagi siswa atau klien tersebut. Guru BK yang profesional tentu memahami layanan apa yang tepat diberikan kepada kliennya dan apa layanan atau kegiatan pendukung yang bisa dikatkan dengan layanan yang sudah diberikan pada siswa atau klien tersebut.

Sebagai contoh sebelum guru BK memberikan layanan konseling perorangan tentu ia sudah mengumpulkan data mengenai pribadi siswa tersebut dan bisa menyesuaikan proses konseling dengan karakter siswa dan masalah yang dihadapi siswa. Proses konseling juga bisa dilalui dengan insedental dimana klien datang secara tiba-tiba kepada guru BK, maka guru BK yang prefesional bisa menyelesaikan dan mengarahkan siswa dengan baik dan tepat.

Keprofesional guru BK dalam pemberian layanan inilah yang bisa mengikis sedikit demi sedikit kesalahfahaman tentang BK. Karena guru BK sudah melakukan hal yang benar dan anggapan yang salah mengenai Bk akhirnya berkurang sedikit demi sedikit dengan profesional yang diperlihatkan oleh guru BK.

Guru BK bisa memperlihatkan kompetensi yang ia miliki, dan orang yang merasakan layanan konseling profesional akan memberitakan kepada yang lainnya bahwa BK itu bagus dan menarik. Sehingga ini menjadi wadah sosialisasi pemasyarakatan BK dari guru BK tersebut.

\section{KESIMPULAN}

Adanya kesalah fahaman mengenai BK hendaknya bisa diminimalisir dengan pelayanan profesional yang diberikan oleh guru BK kepada siswa. Dengan pelayanan yang profesional, diberikan oleh guru BK yang profesional tentu jalannya konseling lebih terarah dibandingkan pemberian layanan konseling dari guru yang tidak berasal dari jurusan BK. Maka guru BK yang profesional melaksanakan pelayanan dalam bentuk keprofesionalnnya dan dengan keprofesionalan ini bisa meminimalisir anggapan yang salah mengenai BK selama ini.

Pentingnya profesional agar guru BK memang menjalankan fungsi dan tugasnya di sekolah. Menjalankan tugas dan funsgi sebagai seorang guru BK tentu akan membuat kesalahfahaman tentang BK lambat laun akan berkurang dan Bk akan dikenal sebagai layanan yang mampu membantu siswa di sekolah.

Guru BK dengan profesional yang dimilikinya dapat mengarahkan siswa dalam penyelesaian masalahnya. Kesalahpahaman mengenai apa itu BK dan bagaimana personil BK dapat diatasi dengan kompetensi guru BK di lapangan. 
Journal of Education and Teaching Learning (JETL)

Volume 3, Issue 1, January 2021

Page 36-49

\section{DAFTAR PUSTAKA}

Abdul Murad. (2011). Tingkat Kinerja Konselor Profesional. Jurnal Ilmu Pendidikan, Jilid 17, Nomor 5, Juni 2011

Anas Salahudin. (2010). Bimbingan dan konseling. Bandung: Pustaka Setia

Ardimen. (2018). Visi Baru Konselor Sekolah dalam Rangka Meningkatkan Kualitas Layanan Pendidikan di Sekolah dan Madrasah. Jurnal Konseling Indonesia http://ejournal.unikama.ac.id/index.php/JKI ISSN: Print 2476-888X Online 2476-8901 Vol. 4 No. 1, Oktober 2018

Hamdan Husein Batubara \& Dessy Noor Ariani. (2018). Penyelenggaraan Bimbingan dan Konseling di Sekolah Dasar. Jurnal Pendidikan: Teori, Penelitian, dan Pengembangan Volume: 3 Nomor: 4 Bulan April Tahun 2018

Hazrullah \& Furqan. (2018). Kompetensi Profesional Guru Bimbingan Konseling Dalam Pemecahan Masalah Belajar Siswa Di MAN Rukoh Banda Aceh. Jurnal Ilmiah DIDAKTIKA Februari 2018 VOL. 18, NO. 2

Mugi Lestari, Mungin Edi Wibowo \& Supriyo. (2013). Kompetensi Profesional Guru BK dalam Pelakasanaan Layanan BK. Indonesian Journal Of Guidance and Counselling: Theory And Therapy, hhtp:/ /journal.unnes.ac.id/sju/index.php/jbk. IJGC 2 (4) (2013)

Ong Didik Cahyo Kartiko, M. Th. Sri Hartati, \& Sinta Saraswati. (2014). Persepsi Siswa Terhadap Kinerja Konselor di SMA Negeri se-Kota Semarang tahun Pelajaran 2013/2014. Indonesian Journal Of Guidance And Counseling: Theory And Aplication http://journal.unnes.ac.id/sju/index.php/jbk. IJGC 3 (4) (2014)

Prayitno. (2004). Dasar-Dasar Bimbingan Dan Konseling. Jakarta: Rineka Cipta

Prayitno. (2009). Wawasan Profesional Konseling. Padang: Universitas Negeri Padang

Prayitno. (2018). Konseling Profesional Yang Berhasil. Depok: PT Raja Grafindo Persada

Shetzer B \& Stone S. C. (1976). Fundamental Of Guidance. Boston: HMC

Sofyan S. Willis. (2009). Konseling Individual Teori Dan Praktek. Bandung: Alfabeta

Tohirin. (2007). Bimbingan dan Konseling di Sekolah dan Madrasah, Jakarta: Raja Grafindo Peserta

Widada. Peningkatan Profesional Guru Bimbingan dan Konseling. Seminar Nasional Pendidikan PGSD UMS \& HDPGSDI Wilayah Jawa. ISBN 978602-70471-2-9 
Journal of Education and Teaching Learning (JETL)

Volume 3, Issue 1, January 2021

Page 36-49

Yenti Arsini. (2017). Konsep Dasar Pelaksanaan Bimbingan Konseling Di Sekolah. Al-Irsyad: Jurnal Pendidikan dan Konseling Vol. 7, NO. 1, Edisi JanuariJuni 2017

Zed, Mestika. (2008). Metode Penelitian Kepustakaan, Jakarta : Yayasan Obor Indonesia 